\title{
A survey of ethnoveterinary botanical remedies in Ogun State and their public health implications
}

Awoyomi, O.J., Biobaku, K.T., Kehinde, O.O. Adebowale, O.O. and Oyewusi, J. A.

College of Veterinary Medicine, FUNAAB

jojuawoyomi@yahoo.com

\begin{abstract}
Twenty four villages were visited during a cross sectional survey of ethno veterinary botanic remedies used for the management of animal diseases in four local government areas randon. selected cutting across the four geopolitical zones in Ogun State. A total of 323 households we purposively selected and administered with a semi structured questionnaire. A total of 3 questionnaires out of 323 were used for the analysis in the study. The farmers were assisted the enumerators to fill the questionnaires in their homes: information on househc demography, common animal diseases in the area, botanical remedies used for treatment, $p c$ of plant used, and source of prescription, methods of preparation and administration of the remedies were gathered.Most of the respondents were farmers, majority keeping goats. Out the 319 respondents 110 (34.4\%) admitted using plants in treatment of livestock diseases. Thir two plant species were identified in the study area for treating livestock ailments. Leaves we the plant part mostly used. Adenopusbreviflorus(Pseudocolocynth) is the most commonly us plant for treatment of many animal diseases in both ruminants and poultry. Most comm. livestock diseases condition is mange followed by Peste des petits ruminants; however in poult the most important diseases are Newcastle disease and diarrhoea. Losses to livestock owne were mostly due to infection.There is need for government and non-government intervention curbing the menace of diseases in livestock production. Reasons for utilization of botanic remedies were identified and public health implications of usage of these herbs were discusst In conclusion, there is an urgent need for more of this documentationcum scientific and clinic validation of the claims; if not ethno-veterinary botanical knowledge faces the risk of goingin extinction due to increasing modern veterinary medical intervention.
\end{abstract}

Keywords: Ethnoveterinary, Botanical remedies, Public Health.

\section{Introduction}

Ethno-veterinary medicine covers people's knowledge, skills, methods, practices and beliefs about the care of their animals (McCorkle, 1986). Ethnoveterinary medicine, the scientific term for traditional animal health care, provides low-cost alternatives to allopathic drugs, (FAO, 2008). Many of these medicines involve the use of botanicals. The implication of ethno-veterinary botanicals is of importance to public health. Many people using these products have the wrong notion of absolute safety vis-à-vis the conventional drugs in animals. The FAO, (2008) redefined the perspective of public health implication of a particular product for human consumers. It involves physical, mental and social effect of the particular issue or product. It is important to understand the different botanicals and pharmacological products have impact on environment and food safety. 
In recent times, there has been an increased awareness of the importance of herbal medicine in the human health care. Efforts are being made in different countries to carry out researches into herbal medicine. Hence there is a need to take a current inventory of common medications used by local farmers in the treatment of rural household livestock diseases.

Animal diseases are a major constraint to livestock production. There is no doubt that plants are very effective in the treatment of diseases and serve as food. The contribution of plant-derived drugs in modern times is still significant and much interest is being focused on exploiting the wide diversity of traditional systems of Medicare and modern drug development. The original profession practiced by man includes plant identification, farming and hunting. Traditional medicine is the most ancient method of curing diseases and it has been said that plants are the very first and the only one true medicine ever used. Rural dwellers in developing countries including Nigeria wholly or partially rely on traditional herbal medicine for treatment and control of animal and human diseases (Sofowora, 1993). In Nigeria traditional veterinary practices play important roles in many rural areas (Kudi and Myint, 1999). Many farmers are aware of animal diseases, but they often resort to various means and use of traditional method of Medicare as the main method of treatment due to unavailability and high cost of veterinary drugs in most pharmaceutical shops and local markets (Musa et al., 2008).

Animal production plays an important role in livelihoods of rural dwellers. The nomads and most people engaged in farming are peasants whose philosophies encourage the use of effective herbal remedies. The herbs used in our rural areas need to be standardized to minimize associated misuse and toxicities. Furthermore the protection of our rich flora including medicinal plants should be a matter of great concern, and conservation of plants is necessary as it ensures the availability of plants for traditional herbalists, traditional healers and herb sellers. There are, however, certain problems faced by the local farmers who use ethno-veterinary approach to treat their animals. These problems include inconvenience involved in the use or preparation of certain remedies; seasonal availability of certain medicinal plants; paucity of treatments against epidemic diseases; existence of harmful practices; difficulty of standardizing herbal remedies (since the concentration of a critical ingredient in a plant often varies from one location to another); and vagueness of local treatment schedules (Mathias and McCorkle, 1989). In fact, Keengweand Benalo (1996) had revealed that in Nigeria, ethnobotanical knowledge and methods have not been fully documented, studied and popularized for use together with modern veterinary medicine as has been done in Kenya, another African country. Thus thisstudy sought to describe the socio-economic characteristics of the farmers, find out of botanical ethno veterinary remedies used for the management of animal diseases, collect and identify the botanicals and finally examine public health implication of these remedies.

\section{Methodology}

Twenty four villages were visited during a cross sectional survey in four local government areas randomly selected cutting across the four geopolitical zones in Ogun state. The State is located on latitude $3^{0} 35^{1} \mathrm{E}$ and longitude $7^{0} 00^{1} \mathrm{~N}$ with an area of $16,762 \mathrm{~cm}^{2}$ and apopulation of 4,054,272. A total of 323 households purposively 
selected were administered with a semi structured questionnaire based on livestock ownership. A total of 319 questionnaires out of 323 were used for the analysis of which 46 are from villages in Remo, 102 from Egba, 117 from Yewa and 54 from Ijebu (Table 1). The number of respondent was based on the willingness of the prospective respondent to participate as many thought the information was for taxation purpose. All the respondent were Yoruba speaking communities except 40 respondents from Alabata village located in Egba zone, who were Fulani cattle herdsmen.

Information on household demography, common animal diseases in the area, botanical remedies used for treatment, part of plant used, sources of prescription, and methods of preparation and administrationof these remedies were gathered. The farmers were assisted by the enumerators to fill the questionnaires in their homes.Some of the plant were collected and identified at the herbarium of the Department of Forestry, Federal University of Agriculture Abeokuta, Nigeria.

\section{Results and Discussion}

One hundred and eighty three (57.4\%) of the respondent were males and the rest females. Most of the respondents were adult, married with average family size of five. Most of the respondents were Muslims $(61.8 \%)$ and with only $76(23.8 \%)$ having more than primary school education (Table 2).

Primary occupation of most of the respondents was farming (273 or $85.6 \%$ ), only three were civil servants while the remaining were traders and artisans.Of the total respondents, $287(90 \%)$ practiced mixed farming i.e. crop and livestock production while $30(9.4 \%)$ were into animal production only.

Livestock reared by the respondents included goats, sheep, chicken, pigs, cattle and rabbits. Majority keep goats (253or79.3\%) while very few keep rabbit (11 or $0.03 \%$ ) Cattle were mainly reared by the Fulani in Alabata village. Pig keeping predominated in Yewa (Table 3). Livestock were reared mainly for the purpose of income generation (245 or $76.8 \%$ ) (Figures 1 ) and the sources of food for the livestock were through both pasture/browses and farm by-products(Table4).

Out of the 319 respondents 110 (34.4\%) admitted using plants in treatment of livestock diseases, while $209(65.6 \%)$ had no knowledge of herbs usage in animal care. The information about the herbs was mostly gathered from parent (93or 84.6\%) while only 17 (15.4\%) obtained information from neighbours The respondents that use plants for treatmenthave confidence in the effectiveness of this remedy.Seventy seven

Table 1: Geopolitical zones distribution of the respondents

\begin{tabular}{llll}
\hline Geopolitical zone & $\begin{array}{l}\text { Herb user } \\
\text { No. }(\%)\end{array}$ & $\begin{array}{l}\text { Non herb users } \\
\text { No }(\%)\end{array}$ & Total $(100 \%)$ \\
\hline Remo & $11(23.9)$ & $35(76.1)$ & 46 \\
Egba & $43(42.2)$ & $59(57.8)$ & 102 \\
Yewa & $36(30.8)$ & $81(69.2)$ & 117 \\
Ijebu & $20(37.0)$ & $34(63.0)$ & 54 \\
Total & $110(34.5)$ & $209(65.5)$ & 319 \\
\hline
\end{tabular}


Table 2: Socio-economic characteristics of the respondents

\begin{tabular}{|c|c|c|c|c|c|}
\hline $\begin{array}{l}\text { Respondent } \\
\text { characteristics }\end{array}$ & $\begin{array}{l}\text { Herb users } \\
(\%)\end{array}$ & No. & $\begin{array}{l}\text { Non herb users } \\
\text { No }(\%)\end{array}$ & $\begin{array}{l}\text { Total } \\
(100 \%)\end{array}$ & $\chi^{2}$ value \\
\hline \multicolumn{6}{|l|}{ Gender } \\
\hline Male & $76(41.5)$ & & $107(58.5)$ & $183(57.4)$ & \\
\hline Female & $34(25.0)$ & & $102(75.0)$ & $136(42.6)$ & 8.89 \\
\hline \multicolumn{6}{|l|}{ Religion } \\
\hline Islam & $79(40.0)$ & & $118(60.0)$ & $197(61.8)$ & \multirow{4}{*}{6.4} \\
\hline Christianity & $22(25.3)$ & & $65(74.7)$ & $87(27.3)$ & \\
\hline Traditional & $92(5.7)$ & & $26(74.3)$ & $35(11.0)$ & \\
\hline \multicolumn{5}{|l|}{ Religion } & \\
\hline Marital Status & & & & & \multirow{5}{*}{10.53} \\
\hline Single & $4(20.0)$ & & $16(80.0)$ & $20(6.7)$ & \\
\hline Married & $90(40.5)$ & & $132(59.5)$ & $222(69.6)$ & \\
\hline Divorced & $12(26.7)$ & & $33(73.3)$ & $45(14.1)$ & \\
\hline Widowed & $4(12.5)$ & & $28(87.5)$ & $32(10.0)$ & \\
\hline \multicolumn{6}{|l|}{ Family size } \\
\hline Less than 5 & $32(27.8)$ & & $83(73.2)$ & 115( 36.1$)$ & \multirow{4}{*}{6.12} \\
\hline $5-7$ & $70(40.0)$ & & $105(60.0)$ & $175(54.9)$ & \\
\hline $8-10$ & $8(30.8)$ & & $18(69.2)$ & $26(8.2)$ & \\
\hline Above 10 & $0(0.0)$ & & $3(100.0)$ & $3(0.9)$ & \\
\hline \multicolumn{6}{|c|}{$\begin{array}{l}\text { Highest educational } \\
\text { level }\end{array}$} \\
\hline None & $61(50.8)$ & & $59(49.2)$ & $120(37.6)$ & \multirow{4}{*}{30.15} \\
\hline Primary & $30(24.4)$ & & $93(75.6)$ & $123(38.6)$ & \\
\hline Secondary & $19(28.4)$ & & $48(71.6)$ & $67(21.0)$ & \\
\hline Tertiary & $0(0.0)$ & & $9(100.0)$ & $9(2.8)$ & \\
\hline \multicolumn{6}{|l|}{ Primary Occupation } \\
\hline Farming & $103(37.9)$ & & $169(62.1)$ & $272(85.3)$ & \multirow{4}{*}{10.83} \\
\hline Trading & $6(20.6)$ & & $23(79.3)$ & $29(9.1)$ & \\
\hline Artisan & $1(6.7)$ & & $14(93.3)$ & $15(4.7)$ & \\
\hline Civil servants & $0 \quad(0)$ & & $3(100)$ & $3(0.9)$ & \\
\hline \multicolumn{6}{|l|}{ Monthly Income } \\
\hline Less than N20,000 & $26(25.2)$ & & $77(74.8)$ & $103(32.3)$ & \multirow{6}{*}{31.04} \\
\hline $\mathrm{N} 21,000-\mathrm{N} 40,000$ & $27(22.0)$ & & $96(78.2)$ & $123(38.6)$ & \\
\hline $\mathrm{N} 41,000-\mathrm{N} 60,000$ & $11(29.7)$ & & $26(70.3)$ & $37(11.6)$ & \\
\hline $\mathrm{N} 61,000-\mathrm{N} 80,000$ & $1(20.0)$ & & $4(80.0)$ & $5(1.6)$ & \\
\hline $\mathrm{N} 81,000-\mathrm{N} 100,000$ & $2(33.0)$ & & $4(66.7)$ & $6(1.9)$ & \\
\hline Above N100,000 & $43(91.5)$ & & $4(8.5)$ & $47(14.7)$ & \\
\hline \multicolumn{6}{|l|}{ Farming scope } \\
\hline Animal production only & $15(50.0)$ & & $15(50.0)$ & $30(9.4)$ & \multirow[t]{3}{*}{0.14} \\
\hline Crop production only & $0(0.0)$ & & $2(100.0)$ & $2(0.63)$ & \\
\hline Mixed farming & $95(33.1)$ & & $192(60.2)$ & $287(90.0)$ & \\
\hline
\end{tabular}


Table 3: Types of livestock reared by the respondent

\begin{tabular}{lll}
\hline LIVESTOCK & FREQUENCIES & PERCENTAGE \\
\hline Pig & 10 & 3.13 \\
Goat & 36 & 11.29 \\
Rabbit & 2 & .6 \\
Sheep & 34 & 10.2 \\
Chicken & 14 & 4.2 \\
Cattle & 2 & 0.6 \\
Pig and chicken & 2 & 0.6 \\
Goat and Rabbit & 2 & 0.6 \\
Goat and Sheep & 112 & 35.1 \\
Goat and Chicken & 16 & 5.0 \\
Rabbit and Sheep & 1 & 0.3 \\
Rabbit and Chicken & 1 & 0.3 \\
Sheep and Chicken & 4 & 1.3 \\
Sheep and Cattle & 1 & 0.3 \\
Pig, Goat and Sheep & 1 & 0.3 \\
Pig, Goat and Chicken & 5 & 1.6 \\
Pig, Rabbit and Chicken & 2 & 0.6 \\
Goat, Rabbit and Sheep & 1 & 0.3 \\
Goat, Rabbit and Chicken & 1 & 0.3 \\
Goat, Sheep and Chicken, & 37 & 11.6 \\
Pig, Goat, Rabbit and Chicken & 1 & 0.3 \\
Goat, Sheep ,Chicken and Cattle & & 10.7 \\
TOTAL & 319 & \\
\hline & & \\
& &
\end{tabular}

$(70 \%)$ of these respondents indicated that plants are more effective than modern veterinary medicine. Only ten $(0.9 \%)$ respondents use plants because of the cost of veterinary services. This shows thathigh cost of treatment is not aprimarily reason for using herbs for treating livestock ailments as concluded by Abu and others
(2009).Rashid and others(2010) noted thatlivestock owners in non-industrialized nations of the world still use medicinal plants for the treatment of livestock diseases, either due to lack of access to trained veterinarians and high cost of orthodox medicines, or the held belief that herbal remedies are more efficacious. The 


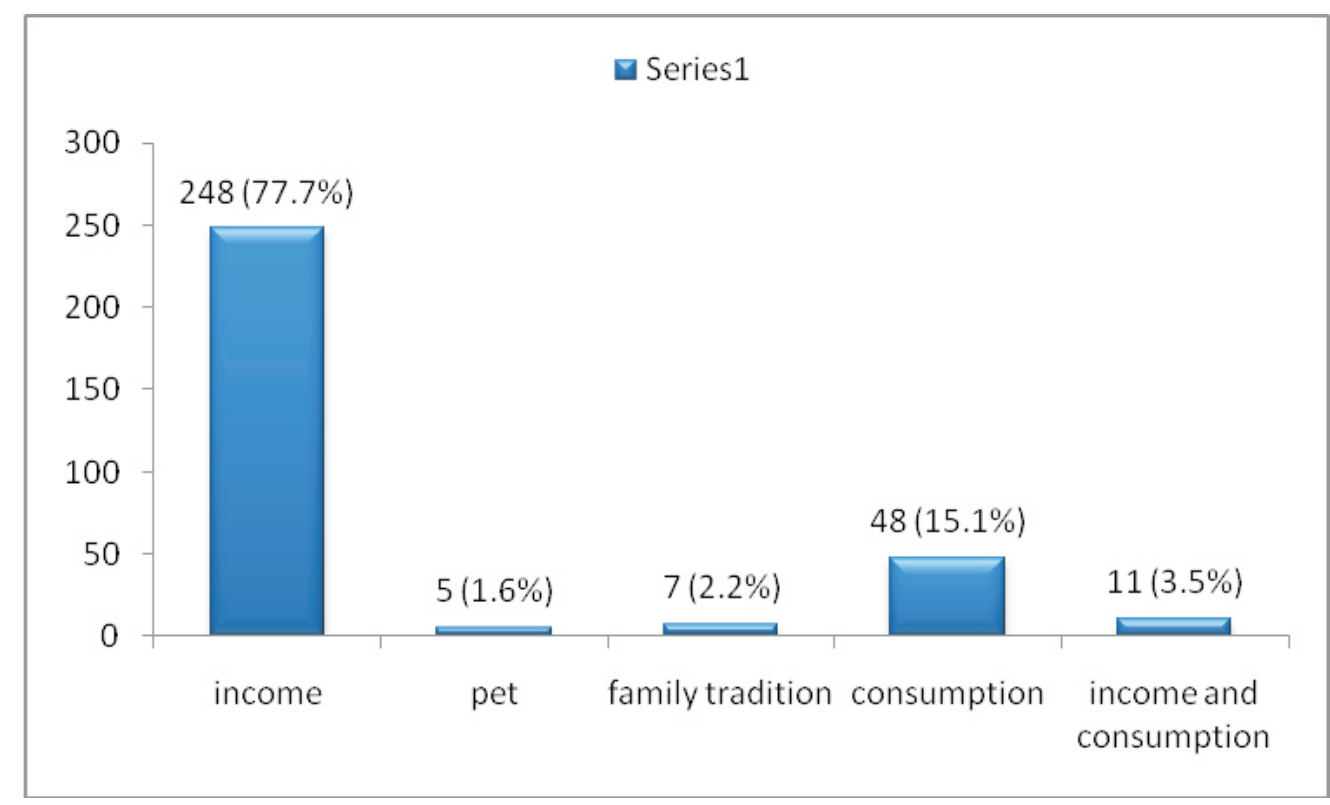

level of confidence imposed on the use of plants may also be due to upsurge of quacks in the field of Veterinary Medicine in the villages that exploit the farmers and at the end no positive results comes from the treatment given to livestock. Most of the plants used were obtained fresh from the farm or nearby forest by the livestock owners or members of the family as at when the need arose, an indication that the plants were not preserved for future use, but are looked for and prepared whenever animals are ill. Consequently, availability of the plant will depend solely on the level of development in each village because the more a forest area is cleared for housing and other purposes less of the plants will be available for treatment of animal ailment (Table 5).

Thirty two plant species were identified in the study location in treating livestock ailment (Table 6). Leaves were the plant part mostly used (16or $48.5 \%$ ) followed by pod,fruit and seeds (9 or $27.3 \%$ ) and mixed parts of the plant ( 8 or $24.4 \%$ ). Some of the medicinalplants identifiedwere pseudocolocynth (Tagiri), sand paper (Eepin), siam weed (Ewe Akintola),

Table 4: Sources of livestock feed

\begin{tabular}{lll}
\hline Sources of livestock feed & Frequency & Percentage \\
\hline Pasture /browses & 40 & 12.0 \\
Farm by products & 50 & 15.0 \\
Others & 7 & 2.1 \\
Pasture /browses and Farm by products & 207 & 62.1 \\
Pasture /browses and others & 5 & 1.5 \\
Farm by products and others & 3 & 0.9 \\
Pasture /browses, Farm by products and others & 7 & 2.1 \\
TOTAL & 319 & 100 \\
\hline
\end{tabular}


Chasmanthera(Ato) and benth (ewe ira or bembeku), others included Rhaphiostylis (Ewe Abe apata), palm tree (ope), purge nut (Ojebotuje) and pawpaw (Ibepe). Pseudocolocynthwas the most commonly used plant for treatment of many animal diseases in both ruminants and poultry. In ruminants it is used for treating mange, fever cold, and in poultry-cough, coryza, coccidisois and New castle diseases, followed by Rhaphiostylis, which is used in the treatment of mange, diarrhoea and New Castle diseases. Most common livestock diseases condition is mange followed by Peste des petitsruminants (with clinical signs of diarrhoea, cough and fever) and wound in ruminants. However in poultry the most important diseases in the study area are Newcastle disease and diarrhoea. The most common cause of loss to livestock owners was infection followed by theft and then automobile accident. (Table7). The livestock owners further indicated that the most needed help is in the area of treatment of animal diseases and vaccination against some preventable animal diseases. There is need for governmental and nongovernmental organizations intervention in curbing the menace of diseases in livestock production. Animal vaccination programme against Peste des petits ruminants(PPR)will go along way in a s sisting the farmers. Routinevaccination programme is being carried out by extension agents (OGADEP) in some villages but $271(85 \%)$ of the respondents indicated that no vaccination campaign was carried out in their villages for the past one year, this could be an indication that some villages are left out of the government annual vaccination campaign,(Table 8). Extension agents need to be more equipped with transport facilities in other to cover more villages in Ogun state.
This study documents a relative diversity of medicinal plants used in traditional medical and ethno-veterinary practices. The medicinal plants used in Ogun State are of different families of the plant kingdom with varying phytochemicals. Many of these plants are used for nutritional therapeutic and prophylactic use (Fahey, 2005). The frequent use of these medicinal plants may predispose the animal to residual tissue accumulation of some of the phytochemicals in the plants.

The residues in meat would be of diverse chemical constituents that predispose to varying syndromes of chronic toxicities (Mikail et al, 2002). However, few of these medicinal plants could be fairly safe. But one or more of these phytochemical constituents could interact and results to additive toxicity that could be detrimental to human.

Humans may be predisposed to various toxicities such as skin allergy due to chemical irritation on mechanical contact from Jatropha curcas (Lampe and Fagerstrom, 1968). Jatropha treated animal products may cause neurological depression (Laxane et al.,2013), autonomic nervous signs, salivation and sweating (Consroe and Glow, 1975).Atropine-like toxicity (Aplin, 1976) with signs of mydriasis, dry mouth, hot skin, tachycardia, gastrointestinal involvement, hepatotoxicity, renotoxicity and in some instances carcinogenic tendencies ( Sofowora ,1993) have been reported

Prolonged usage of Ficus exasperates leading to its residues in products of meat and milk could predispose to nephrotoxicity and renal insufficiency in the consumers. Adebayo et al. (2009), is of the opinion that its antimicrobial effects in animals may have adverse effects on man after the consumption of animal products with Fiscus phytochemical constituents 
Table 5: Information on herb usage by livestock farmers using herbs

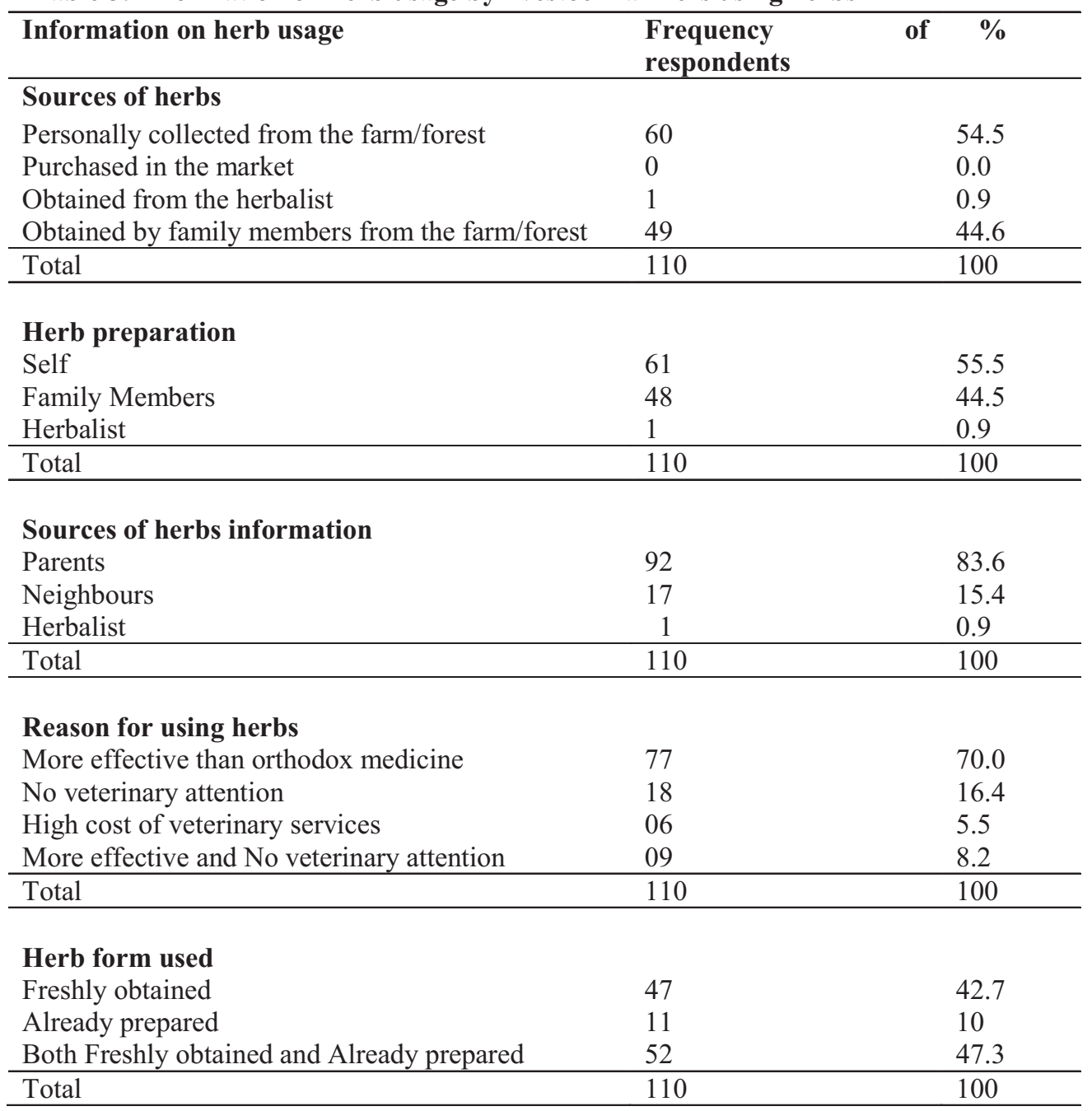


consistently at a prolonged interval resulting to super-infection gastrointestinal floral disturbance leading to diarrhea.

Ocimum gratissium contains saponins, terpenes, and glycosides. These are suggested to cause hepatoxicity. Their usage was found to cause a dose-dependent decrease in the liver enzymes secretion: alanine aminotransferase (ALT) aspertate aminotransferase (AST) and alkaline phosphatase (ALP) (Effraim et al., 2000)

The toxicities of these plants due to their active principles depend on various factors such as route of exposure, extent of exposure (toxic dose), species of animal, health status of the animal product, (meat or milk), method of processing of product, disease state of animal treated, disease involved, environmental factors such a temperature, relative humidity. Part of the plant used in medicine and concentration of active principles in such parts, time of harvest of the plant. Other factors that affect toxicities of these plants include health status of human subject consuming the food, age, sex, individual response to the active principles in botanicals in meat products, idiosyncrasy, and exposure to previous drugs are also amongst other factors that could influence the toxicity in human consumers

The present study recorded 32 plants used in villages for treatment of sixteen animal diseases, such as ectoparatisim, diarrhoea, PPR, cold, wound, coccidisois, coryza and New Castle Disease. Due to the fact that the knowledge of ethno veterinary medicine is being passed on from generation to generation, it faces the risk of extinction due to increased western education and the young generations are less interested in learning traditional medicine. In order to safeguard extinction of traditional animal health care knowledge and also prevent misuse of plants, local traditional medical knowledge should continue to be studied and documented. Also, efficacy and safety of these plants should be investigated to protect both animals and the public. The need to strengthen the existing extension services in Nigeria as a country through adequate and consistent funding cannot be over emphasized for ultimate efficiency. The efforts of both University based extension services and that of the Ogun state Agricultural Development Programme(OGADEP) should be synchronized for better efficiency.

\section{Acknowledgement}

This research was sponsored by IFSERAR, Federal university of Agriculture Abeokuta w i th the grant number UNAAB/IFSERAR/IRG79.

\section{References}

Abu, A.H., Ofukwu R.A. and Mazawaje, D. 2009. A Study of Traditional Animal Health Care in Nasarawa State, Nigeria, Am.-Eurasian J. Sustain. Agric., 3(3): 468-472.

Adebayo, E.A., Ishola,O.R., Taiwo,O.S., Majolagbe,O.N., Adekeye,B.T., 2009. Evaluation of the menthol extract of Fiscus exasperate stem bark, leaf and root for photochemical analysis and antimicrobial activities.African Journal of Plant Science Vol. 3(12), pp. 283-287.

Aplin, T.E.H. 1976. Poisonous Garden Plants and Other Plants Harmful to Man in Australia. Source Western Australia Department of Agriculture, Bulletin 3964: 1-58.

Consroe, P.F., Glow, D.E, 1975. Clinical 
A survey of ethnoveterinary botanical in Ogun State and their public health implications

Table 6: Plants used in ethnoveterinary medicine in Ogun state

\begin{tabular}{|c|c|c|c|c|c|}
\hline$/ \mathbf{N}$ & Scientific name & Common name & Local name & Uses & $\begin{array}{l}\text { Parts of } \\
\text { Plant }\end{array}$ \\
\hline 1. & Fiscus exasperate & Sand paper & "Epin" & Mange & Leaf \\
\hline 2. & Adenopusbreviflorus & Pseudocolocynth & "Tagiri" & $\begin{array}{l}\text { Mange,PPR,cold,,cough,Newc } \\
\text { astledisease,coccidosis }\end{array}$ & Fruit \\
\hline 3. & Ocimumgratissium & Basil leaves & "Effirin-nla" & Diarrhoea & Leaf \\
\hline 4. & Spiondiasmombin & Hogplum & "Iyeye" & Dystocia and diarrhoea & Whole plant \\
\hline 5. & Moringaoleifera & Drumstick benzolive & "Moringa" & Diarrhoea & Shoot \\
\hline 6. & Citrus auriatifolia. & Lime & "Osanwewe" & Mange and Diarrhoea & Fruit \\
\hline 7. & Carica papaya & Pawpaw & "Ibepe" & Worm infestation & Ripe fruit \\
\hline 8. & Acacia albida & Acasia & Kasia & Diarrhoea & Leaves \\
\hline 9. & Allium sativum & Garlic & "Ayu" & Newcastle disease and cough & Bulb \\
\hline 10. & $\begin{array}{l}\text { Arachis hypogeal } \\
\text { (seed oil) }\end{array}$ & Groundnut & "Epa" & wound and bloat & Fruit \\
\hline 11. & $\begin{array}{l}\text { Chromolaena } \\
\text { odoranta }\end{array}$ & Siam weed & "Ewe akintola" & Diarrhoea, wound & Leaves \\
\hline 12. & mormorrdicacharata & Melon & Egusi & Abscess & Seed \\
\hline 13. & Cocosnucifera & Coconut & "Agbon" olodu & Mange & Fruit \\
\hline 14. & Jatrophacarcus & $\begin{array}{l}\text { Purge nut black } \\
\text { vomit }\end{array}$ & "Ojebotuje" & wound & Sap \\
\hline 15. & Nauclealatifolia & African peach & "Egbon" egbesi & Diarrhoea & Leaves \\
\hline 16. & Annonasenegalensi & African custard apple & "Abo" & Eye infection & Leaves \\
\hline 17. & Hexalobuscrispiflorus. & Hexalous & Apara pod & mange & Pod \\
\hline 18. & $\begin{array}{l}\text { Anthocleistaliebrechtsia } \\
n a\end{array}$ & Cabbage tree & Apaoro & Wound & Leaves \\
\hline 19. & Phylanthusamarus & Amarus plant & Eyinolobe & Eye infection & Leaves \\
\hline 20. & Rhaphiostylisbeninensis & Rhaphiostylis & Ewe-abeapata & $\begin{array}{l}\text { Mange, Diarrhoea and } \\
\text { Newcastle disease }\end{array}$ & Whole plant \\
\hline 21. & Zea mays & Pap & Ogi & diarrhoea & Grain \\
\hline 22. & Caesalpiniabonduc & $\begin{array}{l}\text { Gray-nicker,bonduc } \\
\text { nut }\end{array}$ & Ayoo & Dystocia,worm infestation & Whole plant \\
\hline 3. & Ricinuscommunis & Castor oil plant & Ewe-laaKayogi & wound & Leaves \\
\hline 4. & $\begin{array}{l}\text { Chasmantheradependen } \\
s\end{array}$ & Chasmanthera & Atoo & Fracture & Leaves \\
\hline 5. & Terminaliamacroptera & $\begin{array}{l}\text { Cluster leaf or kalum } \\
\text { pit }\end{array}$ & IgiodanBodi & $\begin{array}{l}\text { Dystocia, wounds and sores, } \\
\text { infections, cough }\end{array}$ & Leaves and root \\
\hline 6. & Vitexdoniana & Black plum & OrinlaBodilohi & Eyeinfectionand diarrhoea & Leaves and stem \\
\hline 7. & Oriza sativa & Rice & Omi iresi & Diarrhoea & Seed \\
\hline 8. & Capsicum fruitescens & Pepper & Ata ijosi & Newcastle disease & Fruit \\
\hline 9. & Brideliaferruginea & Benth & Ewe iraBembeku & Newcastle disease & Leaves \\
\hline 0. & Nicotinarustica & Tobacco leaves & Ewe taba & Lice and ticks infestation & Leaves \\
\hline 1. & Jatrophagossypifolia & Red fignut & Lapalapa pupa & Diarrhoea & Leaves \\
\hline 2. & Elaeisguineensis & Palm oil & Epo pupa & $\begin{array}{l}\text { Mange,Newcastle disease and } \\
\text { abscess }\end{array}$ & Fruit \\
\hline
\end{tabular}


Toxicology of the Desert potato: Two case reports of acute Jatropha macrorhiza root ingestion. Arizona medicine 23(6):475-477.

Effraim, K.D., Salami, H.A., Osewa, T.S., 2000. The effects of aqueous leaf extract of Ocimum Gratissium on Haematological and biochemical parameters in rabbits. African Journal of Biomedical Resources vol3; 175-179.

Fahey, J.W., 2005. Moringa oleifera: A Review of the medical evidence for its Nutritional, Therapeutic, and Prophylactic Properties Part 1.Trees forLifejournal/www.TFL.Journal.org. $\mathrm{php} / 20051201124931586$.

FAO. ( 2008$)$ : Available on http:www.fao.org/AG/AGAINFO/pro grammes/en/vph about.html Accessed on 21 March, 2008.

Keengwe, M. and Benalo, I. 1996. Ethnoveterinary medicine in Kenya: A field manual of traditional animal health care practices. Intermediate Technology Development Group and International Institute of Rural Reconstruction, Nairobi, Kenya

Kudi, A. C. and Myint, S.H., 1999. Antiviral activity of some Nigerian medicinal plant extracts. Journal of Ethnophamarcology, 68:289-294.

Lampe, K.F. and Fagerstrom, R. 1968. Plant Toxicity and Dermatitis - A Manual for Physicians, The Williams and Wilkins Company, Baltimore, Maryland, $231 \mathrm{pp}$.

Mikail, H.G., Ajagbonna, O.P., Muhammed B.Y., Onyeyili, P.A. 2002. Garlic a natural agent for treatment of trypanosomosis. Proceedings of the 39th NVMA conference, Sokoto 2002.

Musa, U., Abdu, P.A., Dafwang, I.I., Katsayal, U.A., Edache, J.A. and Karsin, P.D. 2008 Ethnoveterinary remedies used for the management of Newcastle disease in some selected local government areas of Plateau state Nigeria. Nig. Journ. Pharm. Sci., March, Vol. 7 No. 1, P. 126-130

Rashid MH, Tanzin R, Ghosh KC, Jahan R, Khatun MA, Rahmatullah M. 2010 Anethnoveterinary survey of medicinal plants used to treat cattle diseases in Birishiri area, Netrakona district, Bangladesh. Advances in Natural and Applied Sciences. 4(1):10-13.

Sofowora, A. 1993. Medicinal Plants and Traditional Medicine in Africa, $2^{\text {nd }}$ ed. Spectrum Books Ltd., Ibadan, p. 152.

Laxane S. N., Swarnkar, S., Mruthunjaya K., Sachin B. Z., and Manjunath S. M. 2013. Jatropha curcas: A Systemic Review on Pharmacological, Phytochemical, Toxicological Profiles and Commercial Applications. Research Journal of Pharmaceutical, Biological and Chemical Sciences. 4 (1 ): 9891010

Received: 15/01/13 Accepted: 07/08/13 